\title{
PERANAN PARTAI POLITIK ISLAM DALAM PELAKSANAAN PEMILIHAN KEPALA DAERAH SERENTAK DI INDONESIA
}

\author{
Sri Warjiyati| UIN Sunan Ampel Surabaya| \\ warjiyatisri@gmail.com
}

\begin{abstract}
The Islamic Political Parties in support of simultaneous Regional Head Elections in Indonesia have proven to contribute significantly to a very pluralistic national political system. Increasing the capacity and performance of Islamic political parties directly influences the quality of democracy and the performance of the political system in Indonesia, so that the role of Islamic Political Parties needs to be improved, both in capacity, quality and performance in order to realize the quality of democracy in Indonesia. The birth of Islamic parties in Indonesia today has added to the treasures of democracy in Indonesia, this birth phenomenon is thought to be a manifestation of the re-presence of Islamic political power. The quality of democracy can be influenced one of them through the implementation of simultaneous regional head elections in 2018 which are carried out in a constitutional, peaceful, honest and fair manner. The quality of democracy is also determined by the existence of democratic institutions, actors of democracy, actors' relations with institutions, public issues, and the capacity and strategy of democratic actors in linking between political party platforms that carry candidates with issues of public interest. The success of the substance of the implementation of the Regional Head Election simultaneously can be measured from the effectiveness of the system
\end{abstract}

Keywords: Islamic Political Party, Regional Head Election, Quality of Democracy, Simultaneous Election

Abstrak: Partai Politik Islam dalam mendukung Pemilihan Kepala Daerah secara serentak di Indonesia telah terbukti memberikan kontribusi signifikan dalam sistem perpolitikan secara nasional yang sangat pluralis. Peningkatan kapasitas dan kinerja partai politik Islam berpengaruh langsung dalam peningkatan kualitas demokrasi serta kinerja dari sistem politik di Indonesia, sehingga peran Partai Politik Islam memiliki peran untuk ditingkatkan lagi, baik secara kapasitas, kualitas, dan kinerjanya supaya mewujudkan kualitas demokrasi di Indonesia. Lahirnya partai-partai Islam di Indonesia saat ini 
telah menambah khazanah demokrasi di Indonesia, fenomena lahirnya ini di tengarai sebagai perwujudan dari hadirnya kembali kekuatan politik Islam.

Kualitas Demokrasi dapat dipengaruhi salah satunya melalui penyelenggaraan Pemilihan Kepala Daerah secara serentak Tahun 2018 yang dilaksanakan secara konstitusional, damai, jujur, dan adil. Kualitas demokrasi juga ditentukan oleh adanya institusi demokrasi, pelaku demokrasi, hubungan pelaku dengan institusi, isu publik, serta kapasitas maupun strategi pelaku demokrasi dalam menghubungkan antara platform partai politik yang mengusung kandidat dengan isu-isu yang menjadi kepentingan publik. Keberhasilan substansi pelaksanaan Pemilihan Kepala Daerah secara serentak dapat diukur dari efektifitasnya sistem tersebut.

Kata Kunci : Partai Politik Islam, Pemilihan Kepala Daerah, Kualitas Demokrasi, Pemilu Serentak

\section{Pendahuluan}

Partai Politik Islam dalam percaturan politik pemerintahan kita pada saat ini telah memunculkan rasa kegelisahan dan kecemasan dalam menghadapi pemilihan kepala daerah (Pilkada) secara serentak yang dilaksanakan pada bulan Juni Tahun 2018. Realitas politik ini telah membawa pengaruh besar dalam hubungan Partai Politik Islam dan Demokrasi.

Indonesia adalah negara demokratis yang berdasarkan hukum, karena konstitusi kita secara fundamental telah mengakui dan menjamin kedaulatan pada hakekatnya adalah milik rakyat. Hal ini sebagaimana disebutkan dalam Pasal 1 ayat (2) UUD Negara RI Tahun 1945, bahwa "kedaulatan berada di tangan rakyat, dan dilaksanakan menurut Undang-Undang Dasar."

Pemulihan Kepala daerah yang di selenggarakan secara serentak merupakan sebuah terobosan dalam dunia politik guna untuk demokrasi Indonesia yang semakin berkembang. Hal ini merupakan bagian dari cara atau metode pengaturan alam sistem politik yang sejak era reformasi terus mengalami perkembangan, yang mana dalam hal ini daerah di tempatkan sebagai entitas otonom dan mandiri sejak pilkada serentak di gelar pada pertengahan tahun 2005 sampai saat ini, sehingga hal ini 
memperkuat basis legitimasi kepemipinan politik lokal yang demokratis.

Realitas pelaksanaan pemilihan kepala daerah dalam demokrasi politik kini telah menjadi salah satu bentuk potret praktik, selain pemilihan anggota legislatif dan pemilihan presiden. Parta politik pada kenyataan meskipun di mungkinkan lewat jalur Independen atau perseorangan meskipun sebagian besar kandidat lebih senang maju dengan jalur partai politik, baik melalui partai politik pengusung sendiri ataupun secara koalisi, namun dalam hal ini partai politik masih tetap mempunyai kedudukan penting dalam hal kandisat pencalonan calon pemimpin daerah. Sehingga dalam hal ini sangat penting sekali untuk mencermati perkembangan politik saat ini.

Dalam proses pelaksanaan pemilihan kepala daerah banyak dampak yang akan ditimbulkan, baik berupa dampak positif maupun dampak negatif. Pilkada tidak serentak yang dilaksanakan selama ini di rasakan kurang efesien dan di rasa kurang hemat dari segi penganggaran, dan juga dalam hal penggunaan sumber daya manusia. Di samping itu, dilihat dari sisi politik, Pilkada tidak serentak yang di laksanakan juga cenderung terjadi secara tidak sehat dalam hal pergerakan massa antar daerah. Namun dengan diadakannya Pilkada serentak di rasakan akan lebih efisien dan efektif serta menghemat biaya anggaran, serta bermanfaat untuk mengurangi kecurangan yang di lakukan oleh para cukong dengan melalui mobilisasi massa dan migrasi kekuatan yang berusaha untuk melakukan permainan dalam pilkada. Apabila hal tersebut terjadi, maka hasil dari negosiasi kepentingan tersebut merupakan apa yang di hasilkan dari pilkada serentak tersebut. Secara teoritis, dengan di selenggarakan Pilkada serentak ini sebagai upaya guna mencegah terjadinya hal-hal negatif yang akan terjadi.

Di sisi lain, selain terdapat manfaat dari pilkada serentak juga muncul ketakutan dalam pelaksanaanya, apabila dalam pelaksanaannya dinilai tidak demokratis. Maka akan sangat rawan sekali terjadi Konflik serentak dalam Pilkada serentak. Misalnya konflik yang muncul pada Pilkada serentak tahun 2015 terkait pada 
tujuh daerah yang muncul calon tunggal, seperti Kabupaten Timor Tengah (NTT), Kabupaten Blitar (Jawa Timur), Kota Samarinda ( Kalimantan Timur), Kota Mataram (Provinsi NTB), Kota Surabaya, Kabupaten Pacitan (Jawa Timur), dan Kabupaten Tasikmalaya (Jawa Barat).

Fenomena konflik serentak pada pemilihan kepala daerah serentak dapat pula mempunyai konsekuensi yang lebih besar, di mana di karenakan proses verifikasi yang belum selesai maka daerah yang memiliki calon kandidat yang berjumlah 2 atauu 3 orang masih berpotensi mumculmya kandidat atau calon tunggal. Untuk itu dalam pelaksanaa pilkada secara serentak juga di perlukan pengaturan atau regulasi yang cukup jelas dan kepastian hukum, sehingga konflik nyang memiliki sekala lebih besar dan masif tidak akan timbul lagi. Melihat kondisi tersebut, konflik partai politik Islam juga mempengaruhi dalam menentukan kualitas proses penyelenggaraan pilkada sesuai dengan fungsi partai politik guna untuk mewujudkan aspirasi dan kepentingan masyarakat melalui pemilihan umum, baik legislatif maupun eksekutif.

\section{Pembahasan}

Partai politik merupakan suatu kumpulan beberapa orang yang bergabung menjadi satu kelompok yang terorganisir yang mana para anggotanya memiliki orientasi, cita-cita, dan nilia-nilai yang sejalan. Adapun kelompok ini memiliki tujuan untuk mendapatkan kekuasaan politik dengan cara yang konstitusionil untuk menjalankan kebijaksanaan-kebijaksanaan yang telah mereka buat. Menurut pendapat Roy C Marcidis menyatakan bahwa partai politik (parpol) adalah salah satu hal yang menjadi sebuah keharusan dalam kehidupan dunia politik demokratis yang modern, terkecuali hanya kepada masyarakat tradisional yang memiliki otoritarin sistem dalam sistem politiknya yang mana bertumpu npada tentara dan polisi dalam pemeruntahannya. ${ }^{1}$ Partai politik, sebagai sebuah organisasi di maksudkan supaya

' Roy C. Macridism, "Teori-Teori Mutakhir Partai Politik" (Yogyakarta : PT. Tiara Wacana Yogya, 1996), 17 
masyarakat untuk ikut serta aktif dan bergerak, perwakilan kepentingan rakyat, dalam hal persaingan opini memberikan cara kesepakatan yang baik, serta dalam hal kepemimpinan politik secara damai menyediaka sarana suksesi.

Roy C Macridis dalam pendapatnya menyatakan, Partai politik adalah sebuah perkumpulan atau asosiasi yang berfungsi supaya masyarakat untuk ikut serta aktif, perwakilan kepentingan rakyat, dalam hal persaingan opini memberikan cara kesepakatan yang baik, serta dalam hal kepemimpinan politik secara damai menyediaka sarana suksesi. Oleh sebab itu, dalam sebuah masyarakat yang modern partai politik menjadi sebuah realitas yang umum dalam kehidupan dunia politik. Partai politik di gunakan sebagai alat untuk memerintah dan mendapatkan kekuasaan. Partai politik telah di pakai untuk mempertahankan pengelompokkan yang sudah mapan (seperti gereja) atau untuk menghancurkan status aquo seperti yang dilakukan oleh Bolsheviks pada tahun 1917 pada saat kekaisaran Tsar akan di tumbangkan.

Menurut pendapat Miriam Budiardjo mengatakan bahwa Partai politik merupakan suatu kelompok yang terorganisir yang para anggotanya memiliki orientasi, nilai-nilai dan cita-cita yang sama. Adapun tujuan kelompok ini adalah untuk memperoleh kekuasaan politik dan merebut kedudukan politik yang biasanya di lakukan dengan cara konstitusioniil guna melaksanakan kebijaksanaan-kebijaksanaan mereka. ${ }^{2}$

Sedangkan menurut pendapat Carl J. Fiederich menyatakan bahwa Partai politik merupakan sekelompok nmanusia yang secara stabil terorganisir dengan tujuan untuk merebut dan mempertahankan kekuasaan terhadap pemerintahan bagi pimpinan partainya dan memiliki dasar penguasaan ini memberikan kepada anggota partainya kemanfaatan yang bersifat idiil maupun materiil. ${ }^{3}$

Menurut pendapat Soltau menyatakan bahwa partai politik adalah kumpulan warga negara yang terorganisir sedikit banyak,

2 Miriam Budiardjo, "Dasar-Dasar Ilmu Politik", (Jakarta : PT. Gramedia Pustaka Utama, I99|), 16. ${ }^{3}$ lbid., 161 
yang bertindak sebagai sebuah kesatuan politik dengan memanfaatkan kekuasaanya untuk memilih dan bertujuan untuk melakukan penguasaan pemerintahan dana melaksanakan kebijakan umum kepada mereka. ${ }^{4}$

Sigmund Neumann dalam pendapatnya menyatakan bahwa partai politik adalah organisasi aktivis-aktivis politik yang berusaha untuk melakukan penguasaan pemerintahan serta merebut dukungan rakyat, sehingga partai politik yang di bentuk oleh sekelompok warga negara Republik Indonesia secara suka rela atas dasar persamaan kehendak dan cita-cita guna memperjuangkan kepentingan anggota, masyarakat, bangsa dan negara, melalui pemilihan umum. ${ }^{5}$

\section{Fungsi Partai Politik.}

Menurut pendapat Miriam Budiardjo di dalam sebuah negara modern, partai politik memiliki beberapa fungsi: 6

1. Fungsi komunikasi politik: partai politik memilikiu fungsi guna untuk menyalurkan beraneka macam opini serta kepentingan masyarakat dan mnegkoordinir serta mengatur dengan dengan baik sehingga persaingan yang timbul dalam masyarakat tentang perbedaan pendapat akan berkurang. Dalam kehidupan yang begitu luas pada sebuah masyarakat modern, kepentingan dan aspirasi masyarakat akan lenyap tanpa jejak apabila tidak di gabung dan di tampung dengan aspirasi orang lain yang senada.

2. Fungsi Sosialisasi Politik (Instrument of Political Socialization). Sosialisasi politik dalam ilmu politik di maknai sebagai sebuah proses dari seseorang mendapatkan sikap dan orientasi terhadap fenomena politik di dalam kehidupan masyarakat pada tempat ia berada. Biasanya proses sosialisasi berjalan secara berangsur-angsur dari masa kanakkanak hingga dewasa. Proses sosialisasi politik di laksanakan

\footnotetext{
${ }^{4}$ Ibid., 162

${ }^{5}$ Republik Indonesia, Undang- Undang Republik Indonesia Nomor 3 I tahun 2002, Tentang Partai Politik,8

${ }^{6}$ Miriam Budiardjo, Pengantar Ilmu Politik, (Jakarta : Gramedia, 2000), 163
} 
melalui kursus-kursus kader, Rekrutmen politik, ceramahceramah penerangan, dan lain-lain.

3. Fungsi rekrutmen politik. Dalam hal ini partai politik memiliki fungsi untuk mencari dan mengajak orang yang kompeten untuk ikut serta aktif dalam agenda-agenda politik sebagai anggota partai (political recruitment). Oleh karena itu, partai politik ikut serta dalam hal perluasan partisipasi politik. Serta berusaha untuk menarik kelompok atau golongan muda untuk di jadikan kader yang akan menggantikan pimpinan lama (selection of leadership) yang mana di masa akan datang.

4. Fungsi pengatur konflik. Persaingan dan perbedaan pendapat pendapat merupakan soal yang wajar dalam suasa demokrasi saat inu. Apabila terjadi konflik dalam hal ini partai politik berusaha untuk mengatasinya.

Selain fungsi utama partai politik seperti tersebut di atas, menurut pendapat Ramlan Surbakti partai politik masih memiliki fungsi lainnya, yaitu: Sosialisasi politik, Partisipasi politik, rekrutmen politik, komunikasi politik, pengendalian konflik, kontrol politik, dan pemandu kepentingan. ${ }^{7}$

\section{Definis Partai Politik Islam}

Melihat berbagai macam pengertian partai politik sebelumnya, dapat kita ketahui bersama bahwasanya "partai politik islam" merupakan organisasi dari sekelompok orang Islam yang tergabung dalam sebuah wadah yang menjadikan Islam (Qur'an dan Hadist) sebagai dasar dan cara perjuangannya untuk menyalurkan gagasan, maupun aspirasi dan cita-cita umat Islam dalam suatu negara.

Kemudian bisa dikatakan pula bahwa "Partai Islam" adalah orang yang beragama Islam yang berbentuk suatu kelompok yang membentuk sebuah organisasi politik, yang memiliki ciri-ciri:

\footnotetext{
77 Ramlan Surbakti, Memahami Ilmu Politik, (Jakarta: Grasindo, 1999), |6 | - 12 | 
1. Dalam menentukan visi dan misi perjuangan partai yang di gunakan adalah Islam (Qur'an dan Sunah Rasul serta Syari'ah) sebagai azasnya.

2. Dalam memantapkan perjuangan partai menggunakan Islam (Qur'an, Sunah Rasul, dan Syariah) sebagai landasannya.

3. Menggunakan Islam sebagai dasar ideologi pembentukan anggaran dasar dan anggaran rumah tangga parti

4. Melalui parlementer ataupun ekstraparlementer partai mempunyai program untuk Islam, Umat Islam, serta kesejahteraan umat.

5. Memiliki dasar pendukung, partisan, kader yang seluruhnya beragama Islam.

Beberapa ciri-ciri di atas merupakan karaekteristik khusus dari partai politik Islam dan adapun yang masuk dalam kategori partai politik islam di Indonesia adalah Partai Keadilan Sejahtera (PKS), Partai Kebangkitan Bangsa (PKB), Partai Persatuan Pembangunan (PPP), Partai Bulan Bintang (PBB), dan Partai Amanat Nasional (PAN).

\section{Islam Sebagai Sebuah Platform Partai Politik.}

Dengan berdasarkan Al-Qur'an dan Sunah sebagai sumber kajian dalam ajaran Islam, setiap umat muslim memyakini dan mempercayai bahwasanya skema kehidupan (the sceme of life) yang sanagt jelas sudah di berikan dan di jelaskan dalam kedua sumber ajaran Islam tersebut. Skema kehidupan ini di maknai bahwa setiap muslim yang membangun masyarakat adalah masyarakat yang patuh dan taat pada kehendak Allah SWT, sehingga segala hal yang berkaitan dengan nilai baik dan buruk harus di jadikan ciri atau landasan etis dan moral bagi seluruh dimensi kehidupan bermasyarakat dan pengembangannya. ${ }^{8}$ Sehingga umat Islam mendapatkan tuntutan dalam penanaman

${ }^{8}$ Amin Rais, Cakrawala Islam; Antara Cita dan Fakta, (Bandung: Mizan, 1987), 50- 51. 
nilai-nilai Islami tersebut. Islam tidak hanya sekedar sebuah sistem theologi, namun Islam juga merupakan a complete civilization hal ini di ungkapkan dalam buku Wither Isalam karangan H.A.R Gibb. Nasir juga menyataan bahwa Islam tidak dapat di pisahkan dari segala dimensi kegiatan dan kehidupan manusia. ${ }^{9}$

Dalam Islam permasalahan-permasalahan rohaniyah dengan permasalahan-permasalahn dalam dunia itu tidak bisa di pisahkan, namun Islam mencakup kedalam kedua segi bidang ini. Keduanya di atur dalam hukum Islam, hubungan anatar manusia dengan Tuhannya dan hubungan antar sesama manusia. Melihat hal tersebut, umat Islam membutuhkan kekuasaan politik yang di gunkan sebagai instrumen yang penting dalam melaksanakan nilainilai Islami. Ibnu Taimiyah dalam kitabnya al-Siyasah alSyari'iyyah mengungkapkan bahwa nilai (organisasi politik) dalam kehidupan masyarakat merupana keperluan agama yang sangat penting. Tanpa menggunakan agama sebagai tumpangannya maka tidak akan tegak dan kokoh. ${ }^{10}$ Menurut pendapat Muhammad Asad menyatakan bahwa sebuah negara bisa menjadi benar-benar Islami hanya dengan pelaksanaan yang harus di laksanakan dengan penuh kesadaran dari ajaran Islam dalam kehidupan berbangsa, dan bernegara dan dengan cara mempersatukan ajaran tersebut ke dalam Undang-undang sebuah negara. Sebuah negara disebut negara Islam jika dalam kehidupan rakyatnya yang di dasarkan konstitusi adalah ajara Islam tentang sosio-politik. ${ }^{11}$

Islam dan politik jelas tidak dapat di pisahkan. Nabi Muhammad sendiri ialah seorang politikus handal yang bisa menjadi pemimpin bagi rakyatanya. Bahkan di zaman Islam pertama terdahulu, masjid itu tidak hanya berfungsi sebagai tempat ibadah saja, tetapi juga mempunyai fungsi politik yang sangat

\footnotetext{
9 Dikutip dari Nasir Tamara, "Sejarah Politik Islam Orde Baru", dalam Prisma, No. 5 Thn. XVII, istepil $1988, \mathrm{hlm}$. I.

${ }^{10}$ Ibnu Taimiyah, al-Siyasash al-Syar'iyyah, (Kairo: Dar al-Kutub al-'Arabi, 1952), 174. Lihat juga Ibnu Taimiyah," Majmu' Fatawa Syaykh al-Islam Ahmad Ibnu Taimiyah", jilid XXVIII, disunting oleh Muhammad Abdurrahman Ibnu Qasim, Riyadh: Matabi' al-Riyadh, 1963), 62

"' Amin Rais, Cakrawala Islam..., hlm. 52; Ahmad Syafi'i Ma'arif, Islam dan Masalah Kenegaraan, Jakarta: LP3ES, 1985), 139-140
} 
penting. Bukan saja tempat praktik politik seperti tempat musyawarah, ataupun tempat pembaiatan pemimpin/ kepala Negara, dan lainnya lagi, tetapi masjid juga di jadikan tempat mempelajri teori-teori politik di samping ilmu agama dan lainnya.

Dalam kajian Islam kita telah lama mengenal tentang Fiqh Siyasah yang mana pandagannya bedasarkan bahwa syari'at Islam selain mengatur mengenai ketuhanan, Relasi atau hubungan antara manusia dan Tuhannya ( permasalahan tentang Ibadah) juga akhlak, namun juga termasuk hubungan antara inividu dengan Pemerintah dan Negara(daulah), dan bisa juga hubungan antara rakyat dan pemimpinnya, hubungan pejabat dengan penduduk yang di atur secara lengkap didalam fiqh siyasah. ${ }^{12}$

Para ulama salaf memiliki mengartikan politik dalam dua makna, yakni, Pertama, makna politik secara umum, yakni untuk menyelesaikan permasalahan manusia dan kehidupan dunia mereka dengan menggunakan syari'at Islam sebagai dasarnya, kedua, makna politik secara khusus yakni sebuah pandangan atau pendapat yang dinyatakan oleh seorang pemimpin mengenai hukum dan ketentuan yang di keluakann untuk mencegah terjadinya kerusakan, menangani kerusakan yang sudah terjadi serta untuk menyelesaikan masalah-masalah secara khusus.

\section{Landasan Filosofis Berdirinya Partai Politik Islam}

Teori tentang Politik Islam harus bertolak belakang dengan kaidah umum, yaitu kebebasan, keadilan, kesetaraan serta supremasi hukum juga konsistensi dalam hal bagaimana cara memilih pemimpin, bahwa pemerintah memiliki tugas sebagi pelaksana perundang-undangan atau hukum, memberikan perlindungan terhadap agama serta harus bertanggunga jawab kepada rakyat. Kemudian memberi nasehat, mengevaluasi, memecat dan menggantinya jika di rasa perlu merupakan beberapa dari hak rakyart. Sistem politik harus mampu berdiri kokoh di atas

\footnotetext{
12 Yusuf Al-Qardhawy, Pedoman Bernegara Dalam Persepektif Islam, Terjemah dari Judul Aslinya : As-Siyasah Asy-Syari'yah, (Jakarta: Pustaka Al-Kautsar, 1999), 23
} 
prinsip syuto, dan syuro oleh penguasa adalah salah satu hal yang harus di tegakkan.

Sistem politik dalam Islam seharusnya memuat pandangan secara jelas mengenai kebebasan politk, partai politik, kritik politik, aktfitas politik, kedudukan wanita, sistem sosial, pemerataan ekonomi, kebebasan pers, kelayakan dan independensi peradilan. ${ }^{13}$

Dengan begitu ada beberapa landasan filosofis mengenai berdirinya partai Islam, antara lain:

1. Manusia sebagai khalifah di bumi pada kenyataannay memiliki tugas yaitu: memelihara, mengatur, dan memakmurkan bumi yang menjadi tempat yang otentik dalam aktifitas politik.

2. Inti pemahaman kaum muslimin telah terjadi di Universitas Islam tentang Islam dan segala sesuatu tentangnya "Islam adalah sistem hidup yang universal, mencakup seluruh aspek, Islam adalah negara dan tanah air, pemerintahan dan umat, moral dan kekuatan, rahmat dn keadilan, kebudayaan dan perundang- undangan, ilmu dan peradilan, materi dan sumber daya alam, usaha dan kekayaan, jihad dan dakwah, tentara dan fikroh, akidah yang lurus dan ibadah yang benar-benar keuniversalan itu sebagai inti dan pokok-pokok ajaran islam yang bernilai perintah kepada kaum muslimin untuk diterapkan secara utuh. Islam adalaha suatu tata hidup yang meliputi agama, politik, negara, dan masyarakat.". ${ }^{14}$

Sistem politik selain di kaitkan dengan negara, sistem politik juga merupakan sebuah konsep yang pada sebuah negara di terapkan pada situasi yang konkrit. Dalam pendapatnya Miriam Buadiardjo menyatakan bahwa fungsi dari sistem politik adalah

\footnotetext{
${ }^{13}$ Ahmad bin Hanbal, Musnad, jilid III, 20

${ }^{14}$ Nur Mahmudi Isma'il, M. SC, "Partai (visi, misi dan persepsi)", (Jakarta : Gema Insani Press, 1998), 34
}

\section{\begin{tabular}{l|l}
284 & $\begin{array}{l}\text { al-Daulah } \\
\text { Vol. 9. no. 2. Oktober } 2019\end{array}$
\end{tabular}}


untuk mejaga kelangsungan hidup serta mencapai tujuan dari masyaakat. ${ }^{15}$ Budaya politik (political culture) merupakan salah satu aspek penting dalam sistem politik yang mencerminkan faktor subyektif. Budaya politik merupakan pandangan-pandangan politik yang selurus atau sejalan. Seperti: pandangan hidup secara umum, norma-norma serta pola orientasi dalam kehdiupan politik

Budaya politik dalam sebuah masyarakat memiliki bentuk yang mana sejarah sistem yang berkembang dalam masyarakat sangat mempengaruhinya, dan agama yang terdapat dalam masyarakat tersebut, status sosial, konsep mengenai kekuasaan, kepemimpinan, kesukuan, dan lain sebagainya. Dalam sistem politik umumnya memiliki empat variabel antara lain:

1. Kekuasaan, merupakan cara yang di gunakan untuk mendapatkan hal yang di inginkan seperti dengan sumbersumber yang dibagikan kepada kelompok-kelompok didalam sebuah masyarakat.

2. Kepentingan, yang mana menjadi tujuan yang harus di capai oleh kelompok atau para pelaku politik.

3. Kebijaksanaan, yang secara umum tertuang dalam bentuk perundang-undangan yang merupakan keterkaitan antara kekuasaan dan kepentingan.

4. Budaya politik, merupakan orientasi subyektif terhadap sistem politik oleh individu. ${ }^{16}$

Karena beberapa hal tulah maka partai politik Islam mempunyai tujuan untuk membentuk pemerintahan Indonesia yang berdasarkan ajaran Islam yang kafaah. Sehingga segala kebijakan yang bersangkutan dengan negara dan masyarakat diselesaikan secara musyawarah yang merupakan identitas dan perintah Allah dalam al-Qur'an.

\section{Peran Partai Politik dalam Penyelenggaraan Pilkada Serentak}

\footnotetext{
15 Miriam Budiarjo, "Dasar-Dasar Ilmu Politik", cet-XIX, (Gramedia: Jakarta, 1993), 47 $16 \mathrm{lbid}$,
} 
Dalam Indonesia Partai Politi di tempatkan sebagai pilar utama penyangga demokrasi daalm sistem politik Indonesia. Dengan demikian, peran partai politik menjadi sangat penting dalam pilkada serentak Juni 2018, maka sudah selayaknya jika diperlukan sebuah peraturan perundang-undangan mengenai Partai Politik. Peraturan perundang-undangan ini diharapkan mampu menjamin pertumbuhan Partai Politik yang baik, sehat, efektif dan fungsional. Para elite partai politik seharusnya memiliki kesadaran bahwa penyelenggaraan pemilukada serentak dalam pesta demokrasi tidak hanya sekedar berkaitan dengan kepentingan partai politik namun juga keterlibatan rakyat.

Terlepas menang atau kalah dalam konstalasi politik penyelenggaraan pilkada serentak tersebut, keterlibatan semua pihak harus mampu menunjukkan bahwa dalam demokrasi mereka telah menyumbangkan sesuatu hal yang sangat berharga. Melalui kondisi Partai Politik yang baik, maka pelaksanaan rekrutmen pemimpin atau proses pengkaderan, pendidikan politik dan kontrol sosial dapat di mungkinkan terjadi dengan sehat. Dengan menggunakan partai politik juga, konsensus dan konflik dapat terwujudu sebagai upaya untuk menjadikan masyarakat yang lebih dewasa, konflik yang timbul tidak bisa langsung di jadikan alasan untuk menjadikan partai terpecah belah, namun konflik yang timbul di carikan konsensus sebagai upaya untuk menciptakan partai yang sehat dan fungsional.

Dalam sejarahanya telah di laksanakan 11 kali pemilu setelah kemerdekaan Indonesia pada tanggal 17 Agustus 1945. Partaipartai Islam tersebut tidak pernah ketinggalan untuk mengikuti seluruh pemilu 11 kali tersebut. Pemilu yang di laksnakan pertama kali pada masa kabinet Perdana Menteri Burhanuddin Harahap (Masyumi) pada tanggal 29 September 1955 yang mana peserta dari organisasi parati politik, organisasi kemasyarakatan, maupun perorangan sebanyak 118 peserta parpol yang mengikuti,. Untuk memperebutkan 257 kursi DPR dan 514 kursi Konstituanten. Dari semua peserta pemilu tersebut terdapat 5 parrtai polotik Islam, yaitu Nahdlatul Ulama (NU), Partai Syarikat Islam Indonesia (PSII),

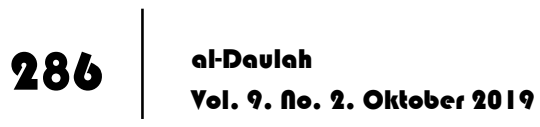


Persatuan Tarbiyah Islam (PERTI), Majelis Syuoro Muslimin Indonesia (MASYUMI), Partai Tharekat Islam Indonesia (PTII).

Pada hasil pemilu tahun 1955, partai-partai Islam mendapatkan hasil yang di rasa bagus meskipun masih kalah suara dengan partai-partai nasionalis. Sebanyak masing-masing 57 kursi di menangkan oleh Masyumi dan PNI pada pemilu DPR, sedangkan Masymui mendapatkan 112 kursi dan PNI mendapatkan 119 kursi di konstiuanten, urutan selanjutnya sebanyak 45 kursi DPR dan 91 kursi d konstituante di tempati oleh NU, selanjutnya 39 kursi DPR dan 80 kursi konstituante di peroleh oleh PKI, selanjutnya PSII mendapatkan 8 kursi DPR dan 16 kursi Konstituante. Sehingga partai Islam mendapatkan 116 dari 257 kursi DPR atau sebesar $45,13 \%$ yang di perebutkan. Sedangkan di konstituante mendapatkan 230 kursi dari 514 kursi konstituante atau sekitar $44,74 \%$ dari jumlah kursi yang di perebutkan.

Permasalahan politik yang paling menjadi sorotan yang di bawa oleh partai politik Islam pada hasil pemilu tahun 1955 adalah permasalahan tentang Ideologi atau dasar negara yaitu Islam, yang bertentangan dengan golongan yang lainnya yang dasar negaranya menggunakan Pancasila serta sosial ekonomi. Hal ini lah yang memicu perdebatan saat itu di Konstituante adalah mengenai Konstitusi Indonesia. Namun perdebatan tersebut dalam hal dasar negara tersebut tidak membuahkan hasil hal ini di karenakan seimbangnya kekuatan Islam dan Nasionalis sehingga tidak mencapai jumlah 2/3 yang di butuhkan. Pada waktu itu, seluruh parrai Islam memandang bahwa Politik merupakan bagian dari syari'at Islam dan Islam dan Politik merupakan satu kesatuan yang tidak dapt di pisahkan. Hal ini terlihat jelas dalam Rancangan Mukaddimah Undang-Undang Dasar yang disusun oleh kelompok Islam yang berbunyi "......Maka untuk memelihara kemerdekaan itu, kami bangsa Indoesia berketetapan hati untuk menyusun Negara Indonesia menjadi Republik berdaulat berdasarkan Islam".

Dalam pidato- pidato pemimpin-pemimpin fraksi Islam menyatakan bahwa gagasan-gagasan dan pertimbangan dasar memilih Islam sebagai dasar negara, yang berkeyakinan bahwa 
selain masalah aqidah, ibadah dan akhlak yang di atur dalam Islam, juga mengatur mengenai hubungan individu dan masyarakat serta negara, di samping alasa demokratis di mana agama mayoritas masyarakat Indonesia adalah Islam.

Pada pemilu kedua pada tanggal 3 Juli 1971 yang di laksanakan pada masa awal Orde Baru. Peserta pemilu terdiri dari sepuluh partai politik pada pemilu kedua ini, di antaranya ada 4 partai Islam yaitu PSII yang mendapatkan 10 kursi, Parmusi yang mendapatkan 26 kursi, NU mendapatkan 58 kursi dan Partai Islam Perti memperoleh 2 kursi, sehingga total terdapat 96 kursi dari 362 kursi DPR yang di peroleh atau sekitar 26,5\% dari jumlah kursi yang di perebutkan. Semenjak pemilu pada tahu 1977 hinga tahun 1997 yakni selama 20 tahun terjadi rasoionalisasi parpol pada masa orde baru yakni hanya terdapat 3 partai politik antara lain Partai Golongan Karya, Partai Demokrasi Indonesia, serta partai Islam yang mana dalam hal ini adalah Partai Persatuan Pembangunan. Pada pemilu 1977 partai Islam semakin memudar hal ini dapat di lihat dari menurunnya jumlah suara yang di peroleh yang mana hanya memperoleh 360 kursi DPR atau sekitar 26,1\% dari jumlah kursi yang di perebutkan, pada pemilu selanjutnya memperoleh 400 kursi atau sekitar 15,25\% dari jumlah kursi yang di perebutkan pada pemilu tahun 1987, pada pemilu tahun 1992 dari 40 kursi hanya mendapatkan $15 \%$ suara, selanjutnya pada pemilu 1997 memperoleh $16 \%$ suara.

Pada pemilu tahun 1999, hasil pemilu menunjukkan bahwa perolehan suara yang di dapatkan partai politik Islam sangat lah kecil apabila di bandingkan dengan perolehan suara yang di dapatkan oleh partai politik yang tidak berdasarakan Islam. Partai Persatuan Pembangunan hanya mendapatkan 58 kursi DPR atau sekitar 12,6\% dari 462 kursi yang di perebutkan meskipun umur dari partai tersebut telah mencapau $1 / 4$ abad, Partai Nahdlatul Ulama hanya memperoleh $1 \%$ suara atau sekitar 5 kursi, Partai Bulan Bintang mendapatkan 2\% suara atau 13 kursi, Partai Keadilan mendapatkan $1,5 \%$ atau 7 kursi, serta 3 partai Islam lain mendapatkan maasing-masing 1 kursi yakni Partai Syarikat Islam,

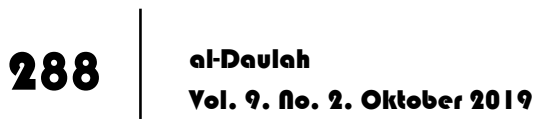


Partai Kebangkitan Ummat, serta Partai Masyumi sehingga total berjumlah 3 kursi atau sekitar 0,64\%. Di sisi lain, partai yang berbasiskan massa Islam pun juga mendapatkan suara yang cukup kecil yaitu Partai Kebangkitan Bangsa mendapatkan 11\% suara atauu 51 kursi dan Partai Amanat Nasional memperoleh 7,36\% suara atau 3 kursi, dengan demikian kedua partai ini total memperoleh 85 kursi atau sekitar 18,36\% suara. Jumlah ini setara dengan perolehan suara yang di dapatkan oleh partai-partai Islam, sedangkan jumlah total kursi yang di dapatkan oleh partai Islam dan Partai berbasis massa Islam adalah sekitar 37\% suara atau 171 kursi.

Selanjutnya, dalam hasil pemilu 2004, total perolehan suara empat partai berasas Islam (PPP, PKS, PPNUI, PBB) hanya 18,77 persen suara nasional. Di dua pemilu berikutnya, total perolehan suara empat partai Islami itupun menurun menjadi 15,15 persen di Pemilu 2009 dan 14,78 persen di Pemilu 2014.

Setelah Pemilu 2014 berakhi, berbagai peristiwa politik dengan corak agama menghiasi jalannya pemerintahan. Fenomena 212, penguatan nilai kesantrian, hingga gerakan-gerakan lainnya melahirkan penguatan nilai dari politik identitas. Lembaga Survei Indonesia pada akhir Januari 2018 merilis hasil elektabilitas partai politik untuk kebutuhan pilkada serentak 2018 dan pemilu 2019. Partai Islam yang mampu meraih elektabilitas tertinggi yaitu PKB dengan persentase 6 persen, di susul PKS 3,8 persen, PPP 3,5 persen, dan PAN 2 persen.

\section{Kerangka Teoritis Demokrasi Konstitusional dalama Penyelenggaraan Pilkada Serentak}

Pilkada serentak yang di selenggarakan dan di laksanakan secara bertahap yang di mulai pada tahun 2015, selanjutnya tahap kedua kemarin di selenggarakan pada tanggal 15 Pebruari 2017 untuk kepala daerah yang masa jabatannya pada semester kedua 2016 telah berakhir dan yang berakhir pada tahun 2017. Kemudian, Pilkada serentak gelombang ketiga di selenggarakan pada tahu 2018 tepatnya bulan juni, selanjutnya tahun 2020, 2022, dan 2023 
hingga tahun 2027 yang akan di selenggarakannya pilkada serentak nasioanl yang mana seluruh wilayah Indonesia menjadi ruang lingkup wilayahnya, pada kurun waktu 5 tahun sekali pilkada serentak menjadi agenda nasional yang rutin di selenggarakan.

Penyelenggaraan pilkada serentak di laksanakan sebagau upaya untuk mewujudkan local accountability, Political Equality, dan Local responsiveness. Pilkada serentak merupakan perwujudan demokratisasi ditingkat local yang berhubungan dengan tingkat partisipasi masyarakat, dan relasi kuasa dengan asas kedaulatan rakyat oleh karena itu output dari pilkada ini harus menciptakan situasi sosial, ekonomi, dan politik pada masyarakat, sehingga dalam pilkada serentak akan menghantarkan sistem pemerintahan yang lebih baik. Selain itu, pilkada serentak yang dilaksanakan dengan lebih professional, demokratis, mampu menimbulkan pengaruh terhadap perubahan politik secara nyata.

Menurut pendapat Beetham secara normatif demokrasi memiliiki tujuan untuk memberikan ruanng kendali rakyat terhadap masalah-masalah publik dengan kesetaraan politik dan solidaritas antara warga Negara sebagai dasarnya yang mana seperangkat prinsip umum yang mensyaratkan tentang hak dan kemampuan bagi semua pihak untuk turut serta berpartisipasi, representasi,otorisasi, dan transparansi dalam pertanggung jawaban. ${ }^{17}$

Keberhasilan penyelengaraan pilkada serentak 2018 yang demokratis, konstitusional, damai, jujur dan adil ditentukan oleh: (1) institusi demokrasi, (2) pelaku demokrasi, (3) hubungan pelaku dengan institusi, (4) isu publik, dan (5) kapasitas maupun strategi pelaku demokrasi dalam menghubungkan antara platform partai politik yang mengusung mereka dengan isu yang menjadi kepentingan publik. Sehingga, keberhasilan substansi pelaksanaan pilkada serentak Juni 2018 yang demokratis, konstitusional, damai, jujur dan adil dalat diukur dari indikator efektifitas bekerjanya institusi Negara, pasar, dan komunitas

\footnotetext{
${ }^{17}$ Beetham, Democraty and Human Rights, (Oxford:Polity Press, 1999), 12.
}

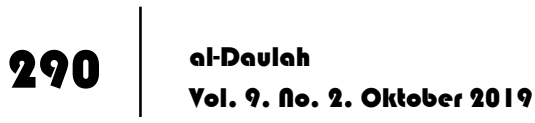


Tidak kalah pentingnya dalam penyelenggraan pilkada serentak Juni 2018 peran dan partisipasi pemilih yang berimplikasi secara politis terhadap legitimasi sebuah pemerintahan yang dihasilkan dari pilkada serentak sehingga untuk pilkada yang akan datang harus bisa mendorong partisipasi pemilih untuk menggunakan hak pilihnya. Legitimasi adalah syarat mutlak yang secara politik turut menentukan kuat tidaknya atau lemah tidaknya suatu pemerintah di daerah. Partai polotik Islam untuk mendorong konsituen pemilih menjadi bagian yang penting dalam proses pelaksanaan pilkada serentak untuk memastikan pilkada dilakukan secara jujur, adil, dan demokratis. Partisipasi partai politik Islam tidak sekedar mendorong konstituen untuk menggunakan hak pilihnya saat pilkada di bilik suara, tetapi juga bagaimana peran partai politik Islam mendorong publik untuk berperan guna menciptakan proses pilkada serentak yang kredibel dan bersih melaluai keterlibatan dalam pengawasan pilkada serentak sebagai bagian kontrol terhadap penyelenggaraan pilkada itu sendiri. Konteks inilah yang kemudian peran serta masyarakat menjadi faktor yang penting untuk menjadikan kualitas pilkada yang baik.

Kontrol dan pengawasan terhadap penyelenggaraan pilkada serentak bertujuan untuk mewujudkan kedaulatan rakyat dalam menggunakan hak pililh sehingga rakyat sebagai warga Negara bisa menyalurkan aspirasi politiknya secara benar tidak ada manipulasi dan bentuk-bentuk kecurangan yang bisa menciderai demokrasi. Kontrol dan pengawasan pilkada serentak seharusnya melibatkan banyak pihak secara luas, dan tidak kalah pentingnya peran media massa untuk mengawal proses penyelenggaraan pilkada serentak dalam semua tahapannya.

Menurut Jimly Asshidiqie, pelembagaan demokrasi memiliki tiga komponen kulifikasi sebagai modus vivendi yang diharapkan dapat mendorong dan mengembangkan demokrasi yang sehat yaitu kompetensi, konstituensi, maupun integritas. ${ }^{18}$ Tiga komponen kualifikasi tersebut merupakan modus vivendi yang

${ }_{18}$ Jimly Asshidiqie, Pergumulan Peran Pemerintah dan Parlemen Dalam Sejarah, (Jakarta : UI Press, 1996),36 
bersifat komulatif bagi demokratisnya kelembagaan demokrasi secara hukum. Kompetensi memberikan efektifitas kepada posisi politik seseorang, dengan tanggung jawab yang harus diberikan kepada komitmen kerjanya dapat diukur berdasarkan prestasi. Selanjutnya, konstituensi merupakan legalitas kepada poisis politik seseorang dengan tanggung jawab yang harus di berikan konstituennya yang berdasarkan dedikasi sebagai ukurannya. Sedangkan memberikan legitimasi kepada seseorang dengan penuh tanggun jawab merupakan sebuah integritas berhubungan dengan tanggung jawab terhadap nilai-nilai serta dasar-dasar yang di gunakan sebagai pegangan atau pedoman, oleh sebab itu di nilai berdasarkan kemampuan resistensi terhadap represi politik, komersialisasi, dan tingkat otonomi berhadapan dengan defiesasi politik.

Dalam pasal 1 angak 1 Undang-Undang Nomor 8 Tahun 2015 menyatakan bahwa Pemilihan Gubernur dan Wakil Gubernur, Bupati dan Wakil Bupati, serta Walikota dan Wakil Walikota adalah pelaksanaan kedaulatan rakyat di wilayah Provinsi dan kabupaten/kota untuk memilih Gubernur dan Wakil Gubernur, Bupati dan Wakil Bupati, serta Walikota dan wakil Walikota secara langsung dan demokratis.

Tahun 2018 adalah tahun pesta demokrasi masyarakat Jawa Timur seluruh rakyat di 38 kabupaten dan kota akan mengikuti pemilihan gubernur dan wakil gubernur juaga dari 38 daerah 18 daerah lainnya menggelar pemilihan kepala daerah. Berdasarkan data KPU Jatim Divisi Perencanaan dan Data terdapat 19 pemilihan kepala daerah serentak itu yakni, pemilihan gubernur Jawa Timur. Sedangkan kabupaten dan kota yang menggelar pilkada yakni: Kabupaten Lumajang, Kabupaten Bondowoso, Kabupaten Probolinggo, Kota Probolinggo, Kabupaten Pasuruan, Kota Malang, Kabupaten Nganjuk , Kabupaten Jombang, Kota Kediri, Kota Madiun, Kabupaten Madiun, Kabupaten Magetan, Kabupaten Tulungagung, Kota Mojokerto, Kabupaten Bojonegoro, Kabupaten Bangkalan, Kabupaten Sampang dan Kabupaten Pamekasan. 
Peran partai politik islam dalam pilkada serentak yang akan diselenggarakan pada bulan Juni 2018 bertujuan mewujudkan pemilihan umum yang baik. Peran disini maksudnya meminimalisir tindakan kekerasan politik, menurunkan keluhan perilaku kecurangan, serta menghindarkan keributan yang masif sehingga penyelenggaraan pilkada dapat berjalan dengan lancer. Untuk mewujudkan pilkada serentak 2018 harus tetap diapresiasi hasil kerja pemerintah, KPU, BAWASLU, dan stake holders lainnya.

\section{Tantangan Partai Politik Islam}

Hubungan Islam dan politik pada kaum muslim di Indonesia senantiasa menjadi kajian yang menarik untuk di ikuti. Hal ini di karenakan selain mayoritas penduduk Indonesia beragama Islam, juga menjadi faktor penentu dalam berbagai macam perubahan baik perubahan dalam sosial, politik, budaya, ekonomi, serta keagamaan pada bangsa ini. Hal lain yang membedakan situasi politik umat Islam di Indonesia dengan negara yang lainnya adalah perubahan dari waktu ke waktu yang bersifat heterogen, bukan bersifat homogen dalam hal pemahaman keagamaan, identitas politim serta aspirasi politik. ${ }^{19}$

Umat islam yang memiliki posisi strategis dan khusus ini maka menjadikan banyaknya kekuatan sosial dan politik yang semakin gencar untuk mendekati secara serius serta berusaha untuk meraih dukungan sosial dan politiknya. Terbentuknya Ideologi Pancasila, UUD 1945 dan NKRI tidak bisa di pisahkan dari perjuangan kaum Muslim Indonesia yang menjadi pendiri bangsa yang telah berjuang untuk kemerdekaan Indonesia.

Dr. Zuly Qadir, dalam pendapatnya menyatakan bahwa membicarakan hubungan antara umat Islam dan politik memiliki kedudukan yang cukup strategis, hal ini di karenakan dari jumlah penduduk Indonesi dengan total 237 juta jiwa sebanyak 86,7\% adalah beragama Islam secara mayoritas, maka secara politik dan sosiologis dari realitas tersebut memang sangat perlu untuk di

\footnotetext{
${ }^{19}$ Gonda Yumitor, "Partai Islam dalam Dinamika Demokrasi di Indonesia", Jurnal IImu Sosial dan IImu Politik, Vol I7 No I, Juli 20 I3, 35-50
} 
perhatikan, serta menjadi sesuatu yang relevan untuk menjadi sebuah objek kajian yang menarik untuk dikaji. Hubungan antara politik dan umat Islam merupakan sebuah dampak atau konsekuensi logis dari sistem demokrasi yang diterpakan di Indonesia, walaupun perilaku umat Islam dalam melihat hubungan Islam dan Politik (demokrasi) tersebut berbeda-beda. ${ }^{20}$

Dengan semakin banyaknya parpol Islam yang di dirikan pada era reformasi saat ini, menimbulkan kedinamisan pada panggung perpolitikan di Indonesia, pembicaraan mengenai hubungan Islam dan negara menjadi sebuah hal yang menarik untuk di kaji, terlebih lagi suasana kebebasan politik, memberikan kesempatan dan peluang seluas-luasnya dengan kembalinya aspirasi Islam politik dalam hal penerapan Islam sebagai dasar negara. Dari titik inilah, aliran Islam formalis mendapatkan kembali kesempatan esksistensinya, hal ini di karenakan, pada saat itu Presiden Soeharto lebih condong merangkul kelompok Islam yang moderat dan akomodatif dalam hal kebijakan politik pembangunannya.

Namun pada saat ini pada pasca reformasi partai politik Islam sedikit demi sedikit telah mengalami banyak kemunduran utamanya dalam hal mengikuti pemilu pada tahun 2004, 2009, dan pemilu 2014. Hingga sampai saat ini pun menjelang pilkada serentak bulan juni 2018 pandangan masyarakat tentang elektabilitas dan popularitas tokoh-tokoh yang berasal dari partai politik Islam semakin berkurang. Pada saat ini masyarakat Indonesia lebih cenderung untuk memilih para tokoh yang berasal dari partai nasionalis di tengah-tengan mayoritas masyarakat yang beragama Islam. Pada umumnya, terdapat dua faktor yang menjadi penyebab mundurnya partai Islam tersebut, baik dalam segi internal maupun eksternal. Dalam aspek internal, beberapa hal yang menjadi penghalang partai Islam untuk menang antara lain adalah:

Pertama, dalam kaitannya dengan pemahaman karakter Islam

20 Zuly Qodir, Islam Syariah Vis-à-vis Negara, "Ideologi Gerakan Politik di Indonesia", (Yogyakarta
: Pustaka Pelajar, 2007), 25 \begin{tabular}{l|l}
294 & $\begin{array}{l}\text { al-Daulah } \\
\text { Vol. 9. no. 2. Oktober } 2019\end{array}$
\end{tabular} 
di Indonesia, Islam selama ini lebih sering di artikan sebagai ritual di bandingkan dengan keterlibatan agama dalam segala aspek kehidupan. ${ }^{21}$ Apabila di kaitkan dengan pendapat dari Peter Mandevelle, maka kemunduran dan pengurangan dukungan terhadap parpol Islam di Indonesia dapat di maklumi. Dalam bukunya Peter Mandevelle menyatakan bahwa walaupun dalam sebuah negara mayoritas Islam akan sangat sesuai dalam kehidupan politik dalam masyarakat. Selanjutnya, ia juga memberikan gambaran tentang berbagai macam situasi dan kondisi yang berkaitan dengan politik Islam, beberapa di antaranya adalah mengenai pemahaman teologi secara tekstual, ataupun kooptasi kekuasaan terhadap agama dan pengalaman sekuler dari kehidupan sesorang yang menjadikan membuat jauhnya agama dari politik.

Kedua, dukungan terhadap partai politik Islam mengalami kemunduran di sebabkan karena terjadinya perpecahan di antara umat Isalam sendiri. Clifford Geertz dalam pendapatnya menggambarkan perpecahan ini dengan membagi kelompok Islam menjadi kelompok abangan, priyayi, dan santri. Bahkan dalam makna politik, Zachary Abusa menyatakan bahwa gerakan Islam di Indonesia di klasifikasikan dalam beberapa jenis, seperti gerakan khilafah, pendirian negara Islam, dan kelompok Pluralis demokrasi.

Ketiga, partai politik Islam belum memiliki kemampuan untuk memecahkan permasalahan yang terjadi secara nyata di kalangan masayarakat, seperti isu pengangguran, isu kemiskinan, dan lain sebagainya. Meskipun parati-partai sekuler memiliki kondisi yang hampir serupa namum mereka masih tetap mampu menampilkan diri dengan lebih menarik. Dalam kondisi seperti ini, partai politik islam di Indonesia di rasa masih belum mampu menyaingi partaipartai sekuler yang mana dalam hal ini menjadi platform partai.

Kelompok tersebut secara sederhana terbagi kedalam dua golongan, yaitu kolompok pro demokrasi dan kelompok anti demokrasi. Kelompok yang mendukung demokrasi adalah mereka

2l Mandavelle, Peter. "Global Political Islam", (New York: Routledge, 2007), 2\&। 4 
yang tergabung dalam partai -partai Islam seperti PPP, PBR, PBB, PKS, PKB dan PAN. Di sisi lain, kelompok yang menanatang demokrasi melipiti Dewan Dakwagh Islam Indonesia (DDII), Salafi, dan Hizbut Tahri. ${ }^{22}$

Selain itu, berbagai macam faktor eksternal pun telah memberikan pengaruh dalam pengurangan pemberian dukungan terhadap partai Islam, beberapa di anataranya yaitu: Pertama, pendapat publik yang di bangun oleh media massa ternyata di rasa kurang memguntungkan partai Islam. Berbagai macam opini tersebut menjadikan gerakan Islam memperoleh gambaran yang kurang baik di kalangan masyarakat. Berbagai kelompok Islam yang cenderung dengan tindakan, terorisme, kekerasan, dan kurangnya kemampuan dalam menyesuaikan diri di tengah-tengah perkembangan zaman. Kedua, sistem pendidikan dan sejarah politik Indonesia yang lebih cenderung sekuler. Selama ini, pendidikan Indonesia kurang begitu memberikan perhatian mengenai problem keagamaan. Indonesia sudah merasa mapan dengan Pancasila, yang dinilai mampu mempersatukan berbagai macam golongan dan agama.

\section{Peran Partai Politik Islam Dalam Pilkada Serentak}

Dalam hal penguatan basis dukungan di tingkat lokal (daerah) dan masyarakat bawah Partai politik Islam harus mampu melaksanakannya cara dengan membuat program-program yang memihak terhadap kepentingan rakyat. Banyaknya kasus korupsi yang menimpa para elit ditingkat nasional di situasi apatisme politik di tengah masyarakat, maka adanya pemimpim di tingkat lokal merupakan sebuah harapan yang besar. Para pemimpin di tingkat lokal adalah harapan masa depan bangsa. Oleh sebab itu, dukungan dan perhatian partai Islam di tingkat lokal dan masyarakat bawah ini harus di kuatkan dengan membuat program-program pendampingan di tingkat lokal.

\footnotetext{
22 Leo Suryadinata. "Election and Politics in Indonesia". (Singapore: Institute of South East Asian Studies, 2002), 6.
} 
Dalam kedudukannya sebagai pilar demokrasi, peran partai politik Islam dalam sistem perpolitikan nasional merupakan wadah seleksi kepemimpinan nasional dan daerah. Pengalaman dalam rangkaian penyelenggaraan seleksi kepemimpinan nasional dan daerah melalui pilkada membuktikan keberhasilan partai politik Islam sebagai bagian dari pilar demokrasi. Penyelenggaraan pilkada serentak kemarin dirasa cukup berhasil oleh berbagai kalangan, termasuk kalangan internasional. Dengan konsep ini dapat di katakan bahwa sistem perpolitikan nasional di rasaa sudah mulai sejalan dengan tatanan dalam kehidupan berbangsa dan bernegara yang mana mencakup di dalamnya tentang penataan partai politik Islam sebagai bagian dari partai politik.

Peran partai politik Islam sudah banyak memberikan kontribusi yang secara khusus dalam sistem politik Indonesia, utamanya dalam dimensi kehidupan masyarakat Indonesia yang mudah sekali mengalami perubahan atau dinamis. Apabila kapasitas dan kinerja parpol Islam dapat di tingkatkan, maka hal ini akan memberikan pengaruh besar dalam hal peningkatan kualitas demokrasi dan kinerja sistem politik. Sehingga peran partai politik Islam perlu ditingkatkan kualitas, kapasitas, dan kinerjanya guna mewujudkan kehendak dan aspirasi rakyat dan guna untuk meningkatkan kualitas demokrasi.

\section{Penutup}

Peran partai politik Islam dalam mendukung pilkada serentak telah memberikan kontribusi secara khusus dan spesifik dalam sistem perpolitikan di Indonesia, utamanya dalam dimensi kehidupan masyarakat Indonesia yang mudah sekali mengalami perubahan atau dinamis. Apabila kapasitas dan kinerja parpol Islam dapat ditingkatkan, maka hal ini akan memberikan pengaruh dalam peningkatan terhadap kualitas demokrasi yang cukup besar dan kinerja dalam sistem politik. Dengan demikian, peran dari partai politik Islam perlu di tingkatkan dalam hal kualitas, kapasitas, serta kinerjanya guna menciptakan dan asprasi rakyat dalam peningkatan kualitas demokrasi di Indonesia. 
Partai politik Islam dalam mewujudkan penyelenggaraan pilkada serentak yang konstitusional damai, jujur, dan adil dapat dilihat dari indikator keberhasilan penyelengaraan pilkada serentak 2018 yang demokratis, konstitusional, damai, jujur dan adil. Selain itu, juga sangat ditentukan oleh: (1) institusi demokrasi, (2) pelaku demokrasi, (3) hubungan pelaku dengan institusi, (4) isu publik, dan (5) kapasitas maupun strategi pelaku demokrasi dalam menghubungkan antara platform partai politik yang mengusung mereka dengan isu yang menjadi kepentingan publik. Sehingga, keberhasilan substansi pelaksanaan pilkada serentak Juni 2018 yang demokratis, konstitusional, damai, jujur dan adil dalat diukur dari indikator efektifitas bekerjanya institusi Negara, pasar, dan komunitas.

Dalam pelaksanaan pilkada serentak Juni 2018 yang akan datang agar dapat berjalan sesuai ekspetasi masyarakat yakni sesuai dengan asas pilkada yang lancer, aman, kondusif, jujur, adil, efisien, dan berkualitas maka peran perangkat aturan hukum menjadi hlm yang sangat penting. Masyarakat pun tidak menangguhkan keberlangsungan pilkada serentak hanya kepada penyelenggara pemilu. Dibutuhkan kerja sama partai politik Islam dan seluruh elemen masyarakat untuk mendukung keberhasilan pilkada tersebut.

\section{Daftar Pustaka}

Asshidiqie, Jimly. Pergumulan Peran Pemerintah dan Parlemen Dalam Sejarah, Jakarta : UI Press, 1996. Pengantar Ilmu Politik. Jakarta : Gramedia, 2000

Beetham, 1999, Democraty and Human Rights. Oxford: Polity Press, tt Budiarjo, Miriam. Dasar-Dasar Ilmu Politik, Jakarta : PT Gramedia Pustaka Utama, 1991.

Ismail, Nur Mahmudi. Memilih Partai (visi, misi dan persepsi), Jakarta : Gema Insani Press, 1998.

Ma'arif, Ahmad Syafi'I. Islam dan Masalah Kenegaraan. Jakarta: 


\section{LP3ES, 1985.}

Macridis, Roy C. Teori-Teori Mutakhir Partai Politik. Penerbit : PT. Tiara Wacana Yogya, 1993.

Mandavelle, Peter,. Global Political Islam. New York: Routledge.

Qodir, Zuly. Islam Syariah Vis-à-vis Negara : Ideologi Gerakan Politik di Indonesia. Yogyakarta : Pustaka Pelajar, 2007.

Rais, Amin. Cakrawala Islam: Antara Cita dan Fakta. Bandung: Mizan, 1987.

Ramlan Surbakti. Memahami Ilmu Politik. Jakarta: Grasindo, 1999

Republik Indonesia, Undang- Undang Republik Indonesia Nomor 31 tahun 2002 Tentang Partai Politik.

Suryadinata, Leo. Election and Politics in Indonesia. Singapore: Institute of South East Asian Studies, 2002.

Taimiyah, Ibnu. al-Siyasash al-Syar'iyyah, Kairo: Dar al-Kutub al'Arabi, 1952.

Tamara, Nasir. Sejarah Politik Islam Orde Baru, Prisma, No. 5 Thn. XVII , 1988.

Yumitor, Gonda. Partai Islam dalam Dinamika Demokrasi di Indonesia, Jurnal Ilmu Sosial dan Ilmu Politik, Vol 17. No. 1, Juli 2013. 